\title{
The effect of nutrition counseling on nutritional status for breast cancer patients in dr. Sardjito Hospital, Indonesia
}

\author{
Susetyowati $^{1 *}$, Sri Retna Dwidanarti ${ }^{2}$, Retno Pangastuti ${ }^{2}$, Hanifah Wulandari ${ }^{1}$, Farah Faza ${ }^{1}$, Nadira D'mas \\ Getare Sanubari ${ }^{1}$
}

\begin{abstract}
Background: Nutrition counseling in breast cancer $(B C)$ patients show long-term adherence to a dietary pattern and affect nutritional status and quality of life (QOL).

Objective: We evaluated the effects of nutrition counseling for nutrient intake dan nutritional status improvement among breast cancer patients.

Materials and Methods: This research was conducted in a pre-experimental design; one group pretest-postest design was conducted on 45 BC patients who underwent radiotherapy for five weeks in the Radiotherapy Unit, dr. Sardjito Hospital, Indonesia. Training fieldworkers demonstrated nutrition counseling to 45 participants using a nutrition booklet for BC patients and a food model as an intervention technique. Continuous nutrition counseling was given three times: weeks 1, 3, and 5 of radiotherapy. To obtain nutritional status, we examined anthropometry, biochemical, physical, dietary, and Patient-Generated Subjective Global Assessment (PG-SGA) questionnaire.

Results: Most of the participants had a body mass index (BMI) $\geq 25 \mathrm{~kg} / \mathrm{m}^{2}$ (62.2\%). After the participants received nutrition counseling, there were increases in energy intake, protein, carbohydrate, vitamin $A$, vitamin $C$, and vitamin $E$ amounted to $124.54 \mathrm{kcal}, 8.12 \mathrm{~g}(\mathrm{p}=0.01), 5.84 \mathrm{~g}, 234.43 \mathrm{mg}, 0.042 \mathrm{mg}$, and $0.44 \mathrm{mg}$, respectively. Intake of fruits and vegetables improved on the first, third, and fifth week $(1.44,2.36$, and 4.03 portion/day, respectively) $(p=0.001)$. Handgrip strength $(H G S)$ showed slight improvement $(p=0.081)$. However, HGS ameliorated from $15.85 \mathrm{kgs}$ in the early to $16.97 \mathrm{kgs}$ in the end stage of therapy. Bodyweight decreased $0.28 \mathrm{~kg}$; however, there were no changes in PGSGA score, hemoglobin (Hb), and albumin levels.

Conclusion: Nutrition counseling improves patients' nutrition intake despite no significant alteration in nutritional status. In addition, nutrition counseling for breast cancer patients during radiotherapy is essential to maintain and improve nutrient intake and nutritional status. In the long-term period, it might be affected to improve quality of life.
\end{abstract}

Keywords: Breast cancer, nutrition counseling, nutritional status, radiotherapy

\section{BACKGROUND}

Cancer is a malignant tumor marked by rapid and uncontrolled cell growth and damaged the other tissues $^{1}$. Breast cancer (BC) develops in the mammary glands, milk ducts, and other breast tissues². More than 1 million new cases of BC per year are the most common cancer among women. Hence, $21.4 \%$ of all tumors in women are breast cancer, more than $8-9 \%$ of women once in their lives experience breast cancer. It has become the fifth leading cause of cancer and the second leading cause of death in developing countries after lung cancer. In Asian countries, the number of reported $\mathrm{BC}$ cases is equivalent to that of developed countries such as Europe and Canadian ${ }^{3}$. For example, the prevalence of breast cancer in Indonesia was $1.4 \%$ or approximately 347792 people ${ }^{4}$. Based on GLOBOCAN (IARC), the incidence of breast cancer was $43.3 \%$, and the percentage of death was $12.9 \%^{5}$. This data shows that breast cancer had a percentage of death lower than the incidence so that if cancer can be detected and treated early, the chance of healing will be higher ${ }^{6}$. Risk factors for breast cancer include age, hormonal factors such as early age at menarche, late age of menopause, late age at first pregnancy, nulliparity and use of hormonal therapies, family history or genetic, and personal factors such as personal history, findings from previous breast biopsies, postmenopausal obesity, lack of exercise, and alcohol use ${ }^{7}$.

\footnotetext{
${ }^{1}$ Department of Nutrition and Health, Faculty of Medicine, Public Health and Nursing, Universitas Gadjah Mada, Jalan Farmako, Sekip Utara, Yogyakarta, Indonesia 55281

${ }^{2}$ Dr. Sardjito Hospital, Jalan Kesehatan No. 1, Yogyakarta, Indonesia 55281

*Correspondence: e-mail: susetyowati@ugm.ac.id
} 
Treatments for breast cancer include surgery, chemotherapy, immunotherapy, radiotherapy, or a combination of several therapies ${ }^{8}$. Radiotherapy has side effects such as nausea and vomiting, mucositis, dry throat, and dysphagia. These symptoms can decrease nutrition intake, notably energy, protein, and micronutrients, which affect nutritional status ${ }^{9-}$ 12. Some studies have shown that radiotherapy increases the incidence of malnutrition, as indicated by weight loss. Due to indications of links between better survival after breast cancer, both the American Institute for Cancer Research (AICR) and the American Cancer Society (ACS) currently suggest the maintenance of healthy body weight and the achievement of a dietary pattern rich in fruits and vegetables and whole grains for long-term diseasefree living for BC patients ${ }^{13}$. Among food components, fruits and vegetables attract greater attention to reduce the risk of $\mathrm{BC}^{14}$. The association was observed between intake of fresh fruits and vegetables and risk of breast cancer, in which the higher fruits and vegetable intake, the lower risk of $\mathrm{BC}^{14}$. The fruits and vegetables contain antioxidants as anti-cancer drugs such as vitamin $\mathrm{C}$, folate, fiber, carotenoids, phytosterols, flavonoids, other phytochemicals, and protease inhibitors ${ }^{14}$.

Nutritional status assessment methods that can be used are Body Mass Index (BMI), Middle Upper Arm Circumference (MUAC), body fat percentage, handgrip strength, hemoglobin and albumin serum, and Patient-Generated Subjective Global Assessment (PG-SGA). The PG-SGA is a gold standard method used explicitly for cancer patients and recommended by the American Dietetic Association (ADA) ${ }^{12}$.

Cancer and the side effects of cancer treatment are also associated with reduced quality of life. Therefore, quality of life assessment combined with therapy is necessary to improve a patient's quality of life and survival. European Organization for Research and Treatment of Cancer Quality of Life Questionnaire C30 (EORTC QLQ-C30) is the most common tool to measure the quality of life in oncology patients 15 .

Therefore, nutrition education for $\mathrm{BC}$ patients is being evaluated. It has been shown that long-term adherence to a dietary pattern is a challenge in studies investigating the relationship between diet and disease, notably in $\mathrm{BC}^{16}$. Another previous study revealed a clinically significant improvement in dietary changes, especially in fruit and vegetable consumption, and reduction of red meat after nutrition education intervention. ${ }^{17}$ Sardjito hospital is the central hospital in Central Java, Indonesia, that treats many cases of BC. 1033 cases in 2009 increased to 1420 cases in 2013, and 856 of these had undergone radiotherapy. Although several previous studies showed significant findings of the effectiveness of nutrition counseling in BC patients, there were some limitations. There were limited assessment parameters, such as only using anthropometric or cross-sectional methods; hence, we can not measure the effect of nutrition counseling intervention. Our research was conducted to assess the effectiveness of nutrition counseling that promotes increased food intake, especially energy, carbohydrate, protein, fat, and vitamin $\mathrm{A}, \mathrm{B}, \mathrm{C}$ as antioxidants and the change of nutritional status during radiotherapy.

\section{MATERIALS AND METHODS The Study Design and Populations}

Between August-December 2016, we carried out this pre-experimental study with one group pretest and posttest design in Unit Radiotherapy, Dr. Sardjito Hospital, Yogyakarta Province, Indonesia. We selected the area since Dr. Sardjito Hospital is the biggest hospital in the province, so that the participants could represent any living areas. Participants were selected using the purposive sampling method. The study population consisted of females more than 18 years of age, diagnosed with breast cancer without metastases, who would like to undergo radiotherapy in 1 package for five weeks (25 times of therapy), able to communicate well, and signed the informed consent. This study did not include participants' body weight and height who could not be measured. The study participants $(n=45)$ fulfilling all criteria above were performed by signing the informed consent.

\section{Ethical Approval}

Informed consent was obtained from all individual participants included in the study. The present study was conducted according to the Declaration of Helsinki principles ${ }^{18}$. The Ethical Committee approved this study of the Faculty of Medicine, Universitas Gadjah Mada, Indonesia, and the approval number was KE/FK/894/EC/2016.

\section{Nutrition Counseling}


Trained nutritionists to execute nutrition counseling. We performed nutrition counseling in the typical room in Radiotherapy Unit Dr. Sardjito Hospital, Yogyakarta, Indonesia while, the subject was waiting for their therapy turns. We brought a nutrition booklet about maintaining a healthy diet and overcoming the side effects of radiotherapy for breast cancer patients. We also used fruit packages as a food model and fresh fruits containing antioxidants, such as papaya, banana, grape, and orange during counseling sessions to describe what the patients should consume accurately. The nutrition counseling was given three-session, in the first, third, and fifth week of therapy. Each nutrition counseling session takes 25-30 minutes for explicating counseling goals, explaining the importance of management diet for BC patients, listening to their grievances about diet and health, and rendering some feedback. We gave motivation to all participants while giving nutrition counseling. We monitored any progression based on nutrition assessments for every counseling session in the first 15 minutes. We noted nutrition intake using 24hours food recall to obtain the amount of nutrition intake. The intake is quiet enough if it meets the minimum $80 \%$ of the individual requirement, according to the energy requirement by $32 \mathrm{kcal} / \mathrm{kg}$ ideal body weight, protein by $1 \mathrm{~g} / \mathrm{kgBB}$, fat by $25 \%$ of total energy expenditure, carbohydrate by difference, vitamin A $500 \mu \mathrm{g}$, vitamin C $75 \mathrm{mg}$ and vitamin $\mathrm{E} 15 \mathrm{mg}^{19}$. We also measured nutritional status based on parameter anthropometric (BMI, MUAC, and body fat percentage), physical (handgrip strength/HGS), and patient GeneratedGlobal Subjective Assessment (PG-SGA) and quality of life using EORTC QLQ-C30. Secondary data was recorded to elicit biochemical data (hemoglobin/ $\mathrm{Hb}$ and albumin serum levels). We informed all the data interpretation to the subject and provided some suggestions to improve or maintain their health.

\section{Dietary Assessment}

We interviewed each subject to obtain dietary data using 24-hours food recall. The interview was conducted in each counseling session, represented the day before therapy in the first week, on therapy in the third week, and after therapy in the fifth week. We analyzed the intake of energy, protein, carbohydrate, fat, vitamin $\mathrm{A}, \mathrm{C}$, and $\mathrm{E}$. The total amount of nutrition intake was performed using nutrisurvey. Fruits and vegetables as antioxidants were also qualitatively analyzed to observe the difference between the early and end of the study.

\section{Anthropometric Measurements}

To obtain nutritional status based on the anthropometric parameter, we measured height to the nearest $0.1 \mathrm{~cm}$ using a locally constructed height stick. Participants were asked to remove their footwear, then stand up against the vertical plane with the head, scapula bone, hip, calf, and heel on the plane, and look straight ahead. Weight and body fat mass were measured in light clothing nearest 0.1 $\mathrm{kg}$ using Omron Karada Scan HBF-358 digital weighing scale. Participants were asked to stand up straight without holding on to any object and not carry anything that affected weight. MUAC was measured in centimeters at the midpoint between the acromion and olecranon using Medline. All the measurements were examined two times with 1minute intervals. The two measurements' mean value was considered the participant's value. Yogyakarta Meteorologycal Agency calibrated all the tools mentioned above in April 2016.

World Health Organization (WHO) definitions of threshold values were used for classifying Body Mass Index (BMI) and waist circumference (WC). Body mass index $\left(\mathrm{kg} / \mathrm{m}^{2}\right)$ was calculated as weight $(\mathrm{kg})$ divided by the square of the height $\left(\mathrm{m}^{2}\right)$ and classified into four categories: $<18.5 \mathrm{~kg} / \mathrm{m}^{2}$ is underweight, $18.5-24.9 \mathrm{~kg} / \mathrm{m}^{2}$ is normal, $25.0-29.9$ $\mathrm{kg} / \mathrm{m}^{2}$ is overweight and $\geq 30 \mathrm{~kg} / \mathrm{m}^{2}$ is obesity ${ }^{19}$. Body fat mass was grouped into four categories as follows: under fat $(<21 \%)$, normal $(21-33 \%)$, overweight (33.1-39\%), and obesity $(>39 \%)^{19}$.

Biochemical Analysis, Physical Measurements, Patient-Generated - Subjective Global Assessment (PG-SGA) and Quality of Life (QOL)

The hemoglobin and albumin serum levels were measured in the hospital clinical laboratory using spectrophotometry, bromscerol green, and EnzymeLinked Immunosorbent Assay (ELISA). The category of hemoglobin was grouped into two as follows: $<12$ $\mathrm{g} / \mathrm{dL}$ is low and $\geq 12-15 \mathrm{~g} / \mathrm{dL}$ is normal while, for albumin was grouped into two as follows: $<4$ is low and $\geq 4$ is average.

We measured physical ability using the HGS. At the time of anthropometric measurement, after completing all measurements above, the participants were asked to grab a hand dynamometer with the 
arm position perpendicular to the axial ${ }^{20-21}$. Next, handgrip strength was measured twice with 2 minutes interval using a hand dynamometer. Finally, participants were asked to squeeze the handgrip as hard as possible using the right hand, and the values were recorded in kilograms ${ }^{20-21}$. We grouped the value of HGS into two categories: $\leq 10 \mathrm{~kg}$ is poor and $>10$ is good. The PG-SGA evaluates malnutrition based on several criteria such as shortterm weight loss history, dietary intake, symptoms relating to nutrition, and a functional and physical examination. A score of 0-3 means well-nourished (PG-SGA A), a score of 4-8 means moderately malnourished (PG-SGA B), and a score $\geq 9$ means severely malnourished (PG-SGA C) ${ }^{22}$.

Quality of life (QOL) was determined using questionnaire EORTC QLQ-C30, which consists of five functional scales, which are physical (PF), role (RF), cognitive (CF), emotional (EF), and social functioning scales, and three symptom scales (fatigue, pain, and nausea/vomiting), a global health/QOL scale, and several single items for the assessment of additional symptoms commonly reported by cancer patients (e.g., dyspnea, appetite loss, sleep disturbance, constipation, and diarrhea), as well as the perceived financial impact of the disease and treatment. All items are scored on 4point Likert scales, ranging from 1 (not at all) to 4 (very much). In addition, all functional scales and individual item scores are transformed to a $0-100$ scale with higher values indicating a higher functioning in functional scales and an increased presence of symptoms in symptom scales ${ }^{15}$.

\section{Data Analysis}

Descriptive frequency analysis measured the characteristic of respondents, the adequacy of food intake, the prevalence of malnutrition, and quality of life. In addition, the difference in food intake and nutritional status between the measurement at first and last week of radiotherapy were analyzed using paired t-test, Wilcoxon test, and McNemar test.

\section{RESULTS}

\section{Participants characteristics}

Most of the participants were between 30-50 years of age $(51,1 \%)$ and had a history of surgery and chemotherapy (Table 1).

Table 1. Participants Characteristics

\begin{tabular}{lcc}
\hline \multicolumn{1}{c}{ Variable } & $\mathrm{n}$ & $\%$ \\
\hline Age & 23 & \\
Adult (30-50 years old) & 22 & 41.1 \\
Elderly (>50 years old) & & 48.9 \\
\hline Stage of Disease & 13 & 28.9 \\
Early-stage (0, I, II) & 13 & 28.9 \\
Regional spread (IIIa, IIIb, IV) & 19 & 42.2 \\
Unknown & & \\
\hline History of Surgery & 41 & 91.1 \\
Yes & 4 & 8.9 \\
No & & \\
\hline History of Chemotherapy & 45 & 100 \\
Yes & 0 & 0 \\
No & $\mathbf{4 5}$ & $\mathbf{1 0 0}$ \\
\hline Total & & \\
\hline
\end{tabular}

Overview of the Nutrition Intake and Nutritional Status Nutrition Intake
More than $50 \%$ of participants have a low intake of protein, carbohydrate, vitamin $\mathrm{A}, \mathrm{C}$, and $\mathrm{E}$ in the early study (Graphic 1). 


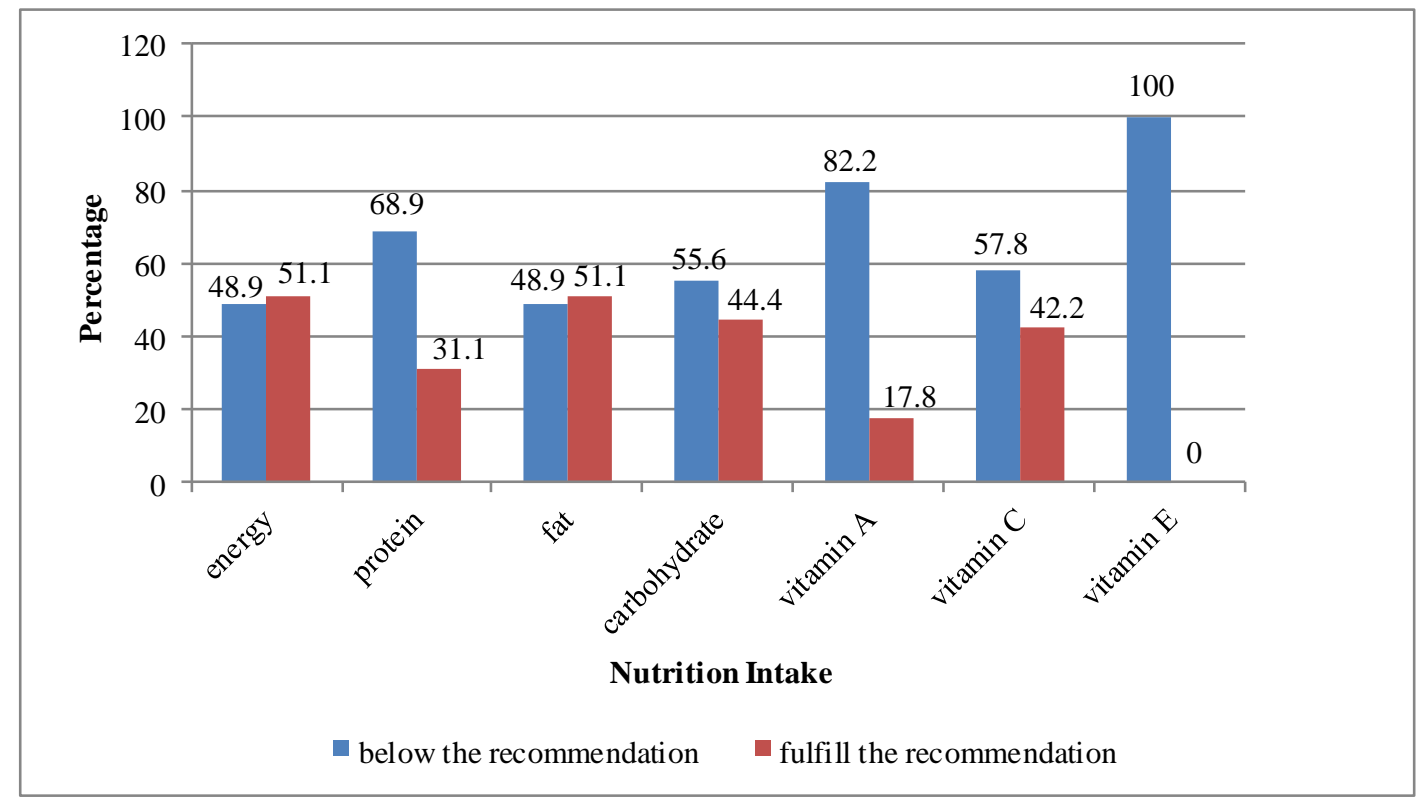

Graphic 1. Nutrition Intake in the Early of Study

Nutritional Status

MUAC, HGS, hemoglobin, albumin, and PG-SGA at early of the study were as below (Table 2).

Table 2 showed that most participants were wellnourished at early radiotherapy. Based on BMI, $31.1 \%$ of participants were well-nourished, and 44.4\% were obese. According to the Application of Clinical Nutrition, the standard of MUAC for an adult woman is $28.5 \mathrm{~cm}^{23}$. MUAC is good if it meets at least $90 \%$ of the standard, $26.65 \mathrm{~cm}$, and $80 \%$ of participants met this standard. Body fat percentage showed that $48.5 \%$ of participants were average, and $37.8 \%$ were overweight. Handgrip strength showed that $77.8 \%$ were good. Based on albumin serum, $90.6 \%$ of participants were average, as did $60 \%$ based on hemoglobin index. However, mostly, participants had a high level of malondialdehyde or MDA (53.3\%). The PG-SGA showed that $73.3 \%$ were well-nourished (PG-SGA A).

\section{Quality of Life}

Overview of the quality of life measured by EORTC QLQ-C30 showed in table 3 as below. Quality of life
Overview of the nutritional status measured by BMI,

assessment is essential to measure the effect of cancer and the treatment on a patient's life and survival. Based on the table, most participants have a good quality of life (70\%).

The Effects of Nutrition Counseling on the Changes of Nutrition Intake

Significant increases were found in protein, fat, and fruits and vegetable consumption at the end of the study. However, intake of energy, carbohydrate, vitamin $\mathrm{A}, \mathrm{C}$, and $\mathrm{E}$ did not significantly increase, as we mentioned in Graphic 2 and Table 4 below.

\section{The effects of Nutrition Counseling on the Changes of Nutritional Status}

The anthropometric and biochemical index after counseling tends to be unchanged in all therapy as presented in Graphic 3 and Graphic 4. 
Table 2. Overview of the Nutritional Status and Quality of Life at Early of Study

Variable $\mathrm{n}(\%)$

\begin{tabular}{lc}
\hline BMI $^{\mathbf{1}}\left(\mathbf{k g} / \mathbf{m}^{\mathbf{2}}\right)$ & \\
Underweight $(<18.5)$ & $3(6.7)$ \\
Well-nourished $(18.5-24.9)$ & $14(31.1)$ \\
Overweight/Obesity $(\geq 25.0)$ & $28(62.2)$ \\
\hline MUAC $\left.\mathbf{1}^{\mathbf{c}} \mathbf{c m}\right)$ & \\
Poor $(<25.65 \mathrm{~cm})$ & $9(20.0)$ \\
Good $(\geq 25.65 \mathrm{~cm})$ & $36(80.0)$ \\
\hline Body fat mass & \\
Underfat $(<21 \%)$ & $4(8.9)$ \\
Normal $(21-33 \%)$ & $22(48.9)$ \\
Overweight $(33.1-39 \%)$ & $17(37.8)$ \\
Obesity $(>39 \%)$ & $2(4.4)$ \\
\hline HGS ${ }^{\mathbf{1}}(\mathbf{k g})$ & \\
Poor $(\leq 10 \mathrm{~kg})$ & $10(22.2)$ \\
Good $(>10 \mathrm{~kg})$ & $35(77.8)$ \\
\hline Albumin serum ${ }^{\mathbf{2}}(\mathbf{m g} / \mathbf{d l})$ & $2(6.3)$ \\
Low & $30(93.7)$ \\
Normal & \\
\hline Hemoglobin ${ }^{\mathbf{2}}(\mathbf{m g} / \mathbf{d l})$ & $11(28.9)$ \\
Low & $27(60.0)$ \\
Normal & \\
\hline PG-SGA ${ }^{\mathbf{1}}$ & $33(73.3)$ \\
PG-SGA A & $10(22.2)$ \\
PG-SGA B & $2(4.4)$ \\
PG-SGA C & \\
\hline
\end{tabular}

${ }^{1}$ BMI: Body Mass Index, MUAC: Mid Upper Arm Circumference, HGS: Handgrip Strength, PG-SGA: Patient Generated-Subjective Global Assessment

${ }^{2}$ Albumin serum was only 32 subjects, and hemoglobin was only 38 since we used secondary data by following the hospital's blood test schedule for BC patients. Therefore, some patients were not assessed until the study finished, especially for the new admission patients.

Table 3. Quality of Life ${ }^{1}$

\begin{tabular}{|c|c|c|}
\hline Quality of Life & $\mathrm{n}$ & $\%$ \\
\hline Good & 28 & 70 \\
\hline Poor & 12 & 30 \\
\hline Total & 40 & 100 \\
\hline
\end{tabular}

${ }^{1}$ Number of subjects was only 40 since several subjects had experienced metastases; hence they were moved to another ward for more intensive treatment.

Table 4. Statistical Analysis of Nutrition Intake in the Early and the End of Therapy

\begin{tabular}{|c|c|c|c|}
\hline Nutrition Intake & Early of Therapy & End of Therapy & \\
\hline & Mean (SD) & Mean (SD) & $\mathbf{p}$ \\
\hline Energy (kcal)* & $1272.14(398.63)$ & $1396.68(406.74)$ & 0.073 \\
\hline Protein $(g) * *$ & $40.27(16.46)$ & $48.39(16.42)$ & $0.010^{1}$ \\
\hline Fat $(\mathbf{g}) * *$ & $33.39(15.69)$ & $41.04(17.65)$ & $0.008^{1}$ \\
\hline Carbohydrate $(\mathrm{g}) *$ & $202.10(74.03)$ & $207.94(74.02)$ & 0.650 \\
\hline Fruits and Vegetables (portion/day)* & $1.44(1.42)$ & $4.03(2.24)$ & $0.001^{1}$ \\
\hline Vitamin A $(\mu \mathrm{g}) * *$ & $266.08(274.52)$ & $500.51(1077.94)$ & 0.379 \\
\hline Vitamin C (mg)** & $88.43(90.46)$ & $88.45(157.33)$ & 0.336 \\
\hline Vitamin E (mg)** & $1.53(1.62)$ & $1.97(1.62)$ & 0.076 \\
\hline
\end{tabular}

*paired t-test, ${ }^{* * \text { Wilcoxon test, }{ }^{1} p<0.05}$

Copyright (C) 2021; Jurnal Gizi Indonesia (The Indonesian Journal of Nutrition), Volume 10 (1), 2021

e-ISSN : 2338-3119, p-ISSN: 1858-4942 


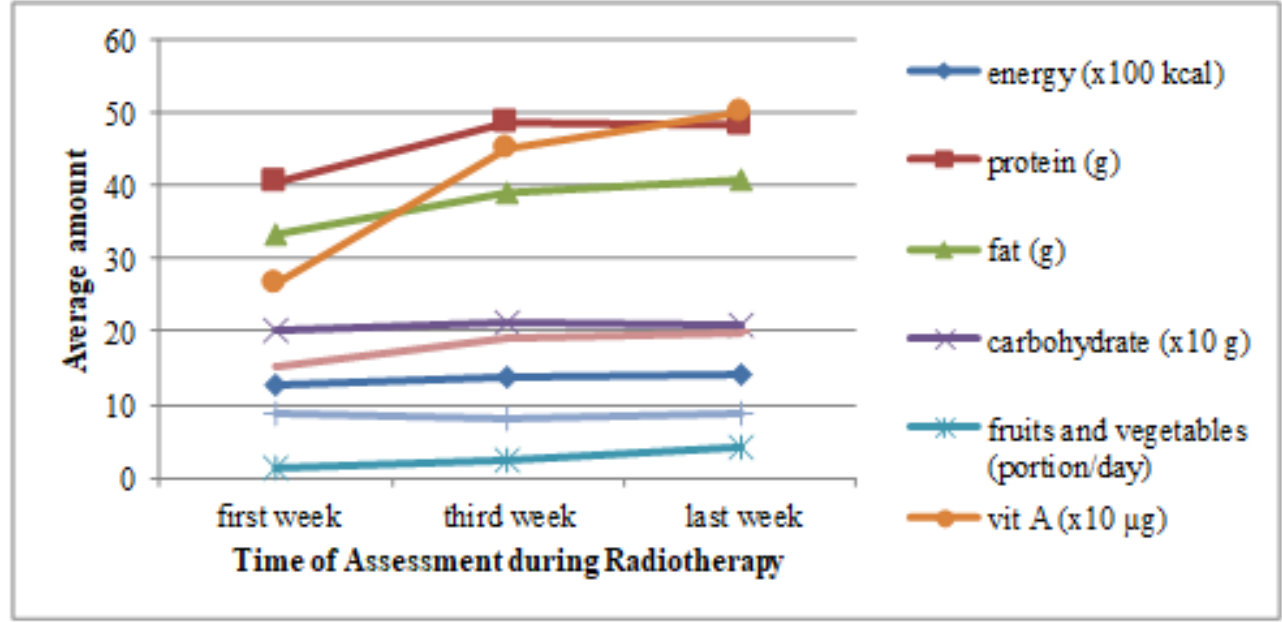

Graphic 2. The Changes of Nutrition Intake during Radiotherapy

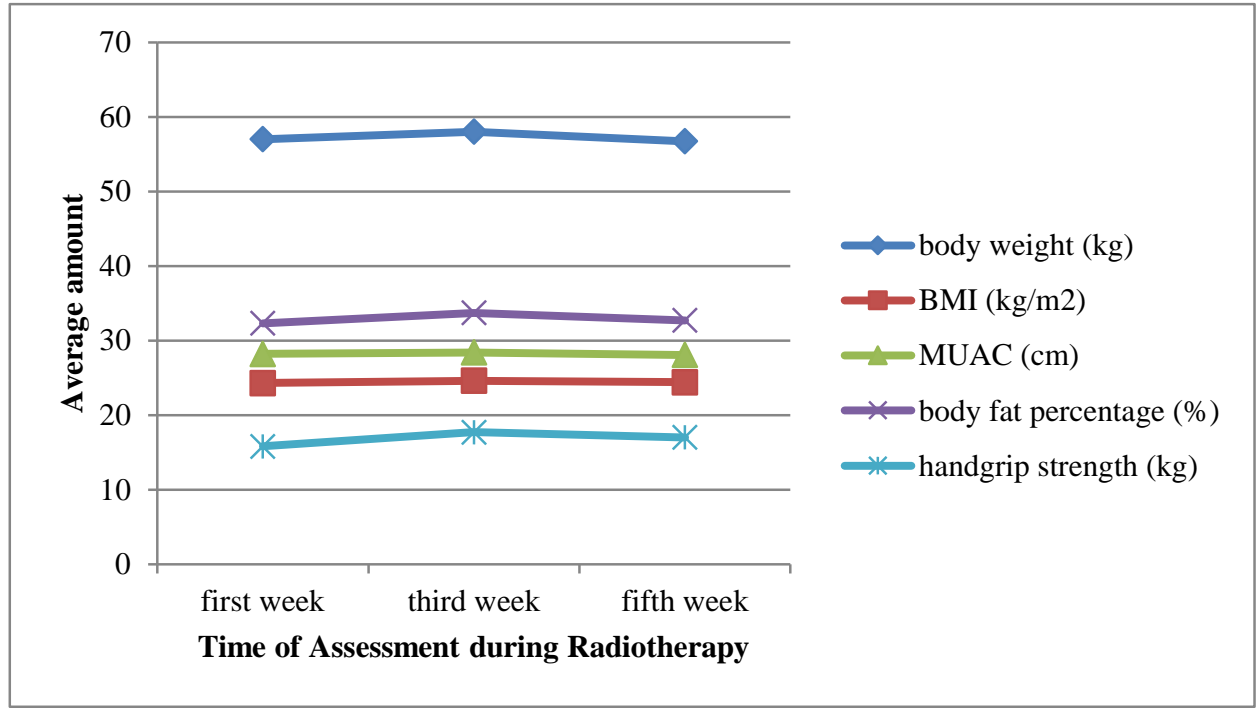

Graphic 3. The Changes of Anthropometric Index during Radiotherapy

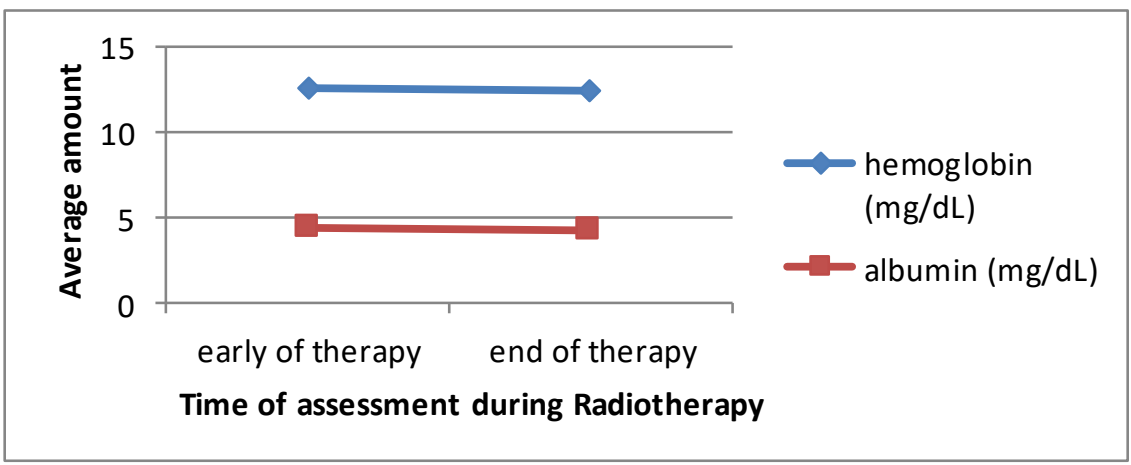

Copyright @ 2021; Jurnal Gizi Indonesia (The Indonesian Journal of Nutrition), Volume 10 (1), 2021 e-ISSN : 2338-3119, p-ISSN: 1858-4942 
Graphic 4. The Changes of Hemoglobin and Albumin Index during Radiotherapy

Based on Table 5, body weight, BMI, HGS, MUAC, body fat percentage, hemoglobin, and albumin index were not significant changes at the end of the study.
However, bodyweight, MUAC, and albumin were decreased while HGS rose at the end of the study.

Tabel 5. Statistical Analysis of Nutritional Status in the Early and the End of Therapy

\begin{tabular}{|c|c|c|c|}
\hline Nutrition Intake & $\begin{array}{c}\text { Early of Therapy } \\
\text { Mean (SD) }\end{array}$ & $\begin{array}{c}\text { End of Therapy } \\
\text { Mean (SD) }\end{array}$ & $\mathbf{p}$ \\
\hline Body weight $(\mathrm{kg}) *$ & $57.00(10.91)$ & $56.72(10.80)$ & 0.075 \\
\hline $\mathrm{BMI}^{1}\left(\mathrm{~kg} / \mathrm{m}^{2}\right)^{*}$ & $24.33(4.28)$ & $24.40(4.24)$ & 0.621 \\
\hline HGS $^{1}$ (kg)* & $15.85(8.78)$ & $16.97(6.18)$ & 0.081 \\
\hline $\operatorname{MUAC}^{1}(\mathrm{~cm})^{* *}$ & $28.20(5.01)$ & $28.06(5.34)$ & 0.352 \\
\hline Body fat percentage (\%)** & $32.29(7.20)$ & $32.71(7.01)$ & 0.576 \\
\hline Hemoglobin (mg/dL)* & $12.59(0.98)$ & $12.53(0.61)$ & 0.346 \\
\hline Albumin (mg/dL)* & $4.37(0.32)$ & $4.30(0.14)$ & 0.838 \\
\hline
\end{tabular}

*paired t-test, **Wilcoxon test, ${ }^{\prime}$ BMI: Body Mass Index, HGS: Handgrip Strength, MUAC: Mid Upper Arm Circumference

Table 6 served the participants who had an excellent handgrip strength at the early study increase after counseling, as did the participants based on PG-
SGA. Nevertheless, one subject changes the score from PG-SGA B turn to PG-SGA C.

Table 6. Statistical Analysis of Handgrip strength and PG-SGA after Counseling

\begin{tabular}{|c|c|c|c|}
\hline \multirow[b]{2}{*}{ Parameters } & \multicolumn{2}{|c|}{ Total Participants } & \multirow[b]{2}{*}{$\mathbf{p}$} \\
\hline & $\begin{array}{c}\text { At the early of } \\
\text { therapy }\end{array}$ & $\begin{array}{l}\text { At the end of } \\
\text { therapy }\end{array}$ & \\
\hline \multicolumn{4}{|l|}{ Handgrip strength $(\mathrm{kg})^{* * *}$} \\
\hline Poor & 10 & 6 & 0.219 \\
\hline Good & 35 & 39 & \\
\hline \multicolumn{4}{|l|}{ PG-SGA* } \\
\hline PG-SGA C & 2 & 3 & 1.000 \\
\hline PG-SGA B & 10 & 8 & \\
\hline PG-SGA A & 33 & 34 & \\
\hline
\end{tabular}

*Marginal homogeneity test, **McNemar test

\section{DISCUSSION}

Most of the participants had an intake of nutrition below the dietary recommendation. More than $48 \%$ of participants had a low energy intake, protein, fat, and carbohydrate. The participants who had an intake of vitamin A below the dietary recommendation were $82,2 \%$, and vitamin $C$ was $57,8 \%$, and vitamin $\mathrm{E}$ was $100 \%$. Based on the early study data, the measurements of BMI, MUAC, body fat percentage, handgrip strength, and PG-SGA presented that most of the participants were wellnourished and tended to be overweight. The hemoglobin and albumin index of participants were mainly normal. At the end of the study, there were some significant and no significant changes in nutritional status and nutritional intake.

Several studies have shown that malnutrition increased in patients treated with radiotherapy who had a low intake of food ${ }^{11-13}$. In addition, there was a significant decrease in body weight, albumin level, and nutritional status based on PG-SGA between the early and the end of radiotherapy ${ }^{11}$. Therefore, nutrition counseling was expected to prevent the decreased nutritional status of a patient.

The nutritional status indirectly by the culture, environment, counseling, employment, or health 
facilities and was directly influenced by food intake and the disease ${ }^{24-25}$. The food intake was influenced by appetite, swallowing ability, and absorption in the body $^{26}$. In cancer, radiation or chemical therapy affects an appetite and causes nausea, vomit, stomatitis, dry throat, and dysphagia. This effect leads to disruption of food intake and decreases the nutritional status9. The nutritional status in cancer patients was influenced by the severity of the disease, the ability of the patient to survive, and the side effects of its therapy ${ }^{27}$. Obesity is the risk of cancer and has been associated with an increased and worse prognosis for malignances ${ }^{28}$.

As mentioned in Table 4, we found significant improvement in protein, fat, and fruit and vegetable consumption after the nutrition counseling session. Protein and fat increased up to 8 grams/day, and fruit and vegetable increased up to 2.5 portions/day. Vitamin A, C, and E are essential for cancer patients treated with radiotherapy. The current research has shown that consuming nutrients in fruits, vegetables, the source of carbohydrates, protein, and fat, will reinforce the body against cancer. Consumption of vitamins, minerals, other phytochemicals, and antioxidants also increases the immune system against carcinogens or toxins, leading to cell damage and oxidative stress. In cancer patients, there are changes in carbohydrates, protein, and fat in the body. Hypermetabolism occurs because the cancer cells increase the glucose needs as energy. It leads to protein turnover and increases lipolysis ${ }^{29}$.

Concerning the increase of nutrient intake in this study, there were no significant changes in body weight and nutritional status parameters such as BMI, MUAC, body fat percentage, and handgrip strength between the early and the end of therapy. However, after counseling, the average difference of body weight was $0.28 \mathrm{~kg}$, the average difference of MUAC was $0.14 \mathrm{~cm}$, and the average difference of body fat percentage was $0.42 \%$. In addition, there was an increase of well-nourished patients based on handgrip strength and PG-SGA after counseling.

Index of hemoglobin and albumin between the early and the end of therapy was decreased but not significant. The average difference of hemoglobin index was $0.07 \mathrm{mg} / \mathrm{dl}$, as did the albumin index was $0.08 \mathrm{mg} / \mathrm{dl}$. Most participants had an average level of hemoglobin and albumin. The patient treated with radiotherapy should have an average hemoglobin level to prevent lack of oxygen in the blood, leading to optimal ionization during radiation ${ }^{30-31}$. The low albumin index is related to the increase in mortality. The low intake of protein causes increases endothelial blood vessel permeability due to cell damage or in an acute condition, leading to a decrease of albumin synthesis in the liver ${ }^{10,32,33}$.

Nutritional status in cancer patients determines to quality of life in the future. Well-nourished patients have better body function and do not appear many symptoms of diseases. In contrast, malnourished patients have lower physical, cognitive and social conditions, and more disease symptoms. These physical, cognitive, social, and symptomatic conditions are a dimension of the quality of life so that cancer patients with good nutritional status have a better quality of life ${ }^{34}$.

Nutrition counseling aims to overcome the nutritional problems of the patient that affect the food intake. Counselor also calculated the nutrient needs and applied them in the daily menu recommendations. This study shows that there was a significant increase in protein and fat intake after counseling. The intake of energy, carbohydrate, vitamins $\mathrm{A}, \mathrm{C}$, and $\mathrm{E}$ was increased but not statistically significant. This means that nutrition counseling has a considerable effect on the patient's intake. The previous studies showed that nutrition counseling also increased the consumption of fruits and vegetables, decreased the consumption of red meat, and there were no changes in body weight and the increase of glutathione ${ }^{16,34}$.

\section{CONCLUSION}

There was a significant increase in protein and fat intake after counseling, but the increase in energy, carbohydrate, vitamin $\mathrm{A}, \mathrm{C}$, and $\mathrm{E}$ was insignificant. In addition, there was no significant difference in body weight, nutritional status based on BMI, MUAC, handgrip strength, albumin and hemoglobin level, and PG-SGA after counseling. The average measurement of body weight, MUAC, hemoglobin, and albumin decreased; however, BMI, body fat percentage, and handgrip strength tended to increase.

\section{ACKNOWLEDGEMENT}

This research is sponsored by the Faculty of Medicine, Public Health, and Nursing, Universitas Gadjah Mada. We are thankful to all participants who had participated in this study and our trained fieldworkers for their endeavor to collect the data. However, the result and interpretation presented here are the author's responsibility. 


\section{REFERENCES}

1. Cancer Helps, T. Stop Kanker: Panduan Deteksi Dini \& Pengobatan Menyeluruh Berbagai Jenis Kanker (Stop Cancer: Guideline for Screening and Holistic Treatment in Cancer). Jakarta: AgroMedia Pustaka. 2010. Available at: https://books.google.com/books?id=8ErRCgAAQBA J\&pgis=1 [Accessed November 2, 2015].

2. Mardiana, L. Kanker pada Wanita (Cancer in Women). Jakarta: Niaga Swadaya. 2007

3. Banning M, Hafeez H. A Two-Center Study of Muslim Women's Views of Breast Cancer and Breast Health Practices in Pakistan and the UK. J Canc Educ. 2010;25:349 - 353 .

4. Indonesia Ministry of Health. Riset Kesehatan Dasar (Basic Health Research). Jakarta. 2013

5. WHO. Globocan 2012: Estimated Cancer Incidence, Mortality and Prevalence Worldwide in 2012. 2012. Available at: http://globocan.iarc.fr/Default.aspx [Accessed November 4, 2016]

6. Coleman MP, Quaresma M, Berrino F, et al. Cancer survival in five continents: a worldwide populationbased study (CONCORD). Lancet Oncol. 2008;9:730-756.

7. Association of Women's Health, Obstetric \& Neonatal Nursing. Breast Cancer Screening. Nursing for Women's Health Journal. 2010;39:608-610.

8. Jong, W. D., Sjamsuhidayat, R. Buku Ajar Ilmu Bedah Edisi Revisi (Modul: Surgery, 2nd edition). Jakarta: EGC. 2004

9. Gazali, F. Kanker Nasofaring: Kenali, Hindari, dan Obati (Nasopharynx Cancer: Recognizing, Preventing, and Treatment). Jakarta: University of Indonesia Press. 2009

10. Mahdavi, R., Faramarzi, E., Mohammad-Zadeh, M., Ghaeammaghami, J., Jabbari, M.V. Consequences of radiotherapy on nutritional status, dietary intake, serum zinc and copper levels in patients with the gastrointestinal tract and head and neck cancer. Saudi Medical Journal. 2007;28(3):435-440.

11. Kiss, N., E. Isenring, K. Gough, M. Krishnasamy. The Prevalence of Weight Loss During (Chemo)radiotherapy Treatment for Lung Cancer and Associated Patient- and Treatment-related Factors. Clinical Nutrition. 2014;22(6):1074-1080.

12. Hong, J.S., Wu, L.H., Su, L., Zhang, H.R., Lv, W.L., Zhang, W.J., Tian, J. Effect of chemoradiotherapy on the nutrition status of the patient with nasopharyngeal cancer. Nutrition and Cancer. 2016;68(1):63-6.

13. Braakhuis A, Campion P, Bishop K. The Effects of Dietary Nutrition Education on Weight and Health Biomarkers in Breast Cancer Survivors. Med. Sci. 2017;5:12.
14. Kooshki A, Moghaddam MY, Akbarzadeh R. Study of Fruit and Vegetable Intake in Breast Cancer Patients in the City of Sabzevar. Electronic Physician. 2016;8(9):3011 - 3014.

15. Cankuntaran, E.S., Ozal, P.E., Soygur, H. Ozer, S. Akbiyik, D.I., Bottomley, A. Understanding the Reliability and validity of the EORTC QLQ-C30 in Turkish cancer patients. European Journal of Cancer Care. 2008; 17:98-104.

16. Schiavon CC, Francilene GKV, Vanessa C, de Liz, S., Cardoso, A.L.., Sabel, C., Gonzalez-Chica, D.A., da Silva, E.L., Galvan, D., Crippa, C.G., Piettro, P.F.D. Nutrition Education Intervention for Women with Breast Cancer: Effect on Nutritional Factors and Oxidative Stress. J Nutr Edu Behavior. 2015;47(1):29.

17. Schiavon C.C; Vieira. FGK., CeccattoS., Cardoso A.1., Sabel C., Gonzalez D, A., da Silva E.L., Galvan D., Crippa C.G., Di Pietro P.F. Nutrition Counseling Intervention for Women With Breast Cancer: Effect on Nutritional Factors and Oxidative Stress. Journal of Nutrition Counseling and Behavior. 2015;47:1.

18. Arie S. Revision of Helsinki declaration aims to prevent exploitation of study participants. BMJ. 2013;347: f6401. DOI. 10.1136/BMJ.f6401.

19. Gibson RS. Principles of Nutritional Assessment, 2nd edition. Oxford University Press: New York, USA. 2005.

20. Prevost, V., C. Joubert, N. Heutte, E. Babin. Assessment of nutritional status and quality of life in patients treated for head and neck cancer. European Annals of Otorhinolaryngology, Head and Neck Diseases. 2014;131:113-120.

21. Janssen S, Glanzmann C, Lang S, Verlaan S, Streller T, Wisler D, Linsenmeier C, Studer G. Hypofractionated Radiotherapy For Breast Cancer Acceleration Of The START A Treatment Regime: Intermediate Tolerance And Efficacy. Radiation Oncology. 2014;9:165.

22. Almatsier S. Penuntun Diet (Guideline in Diet). Jakarta : PT. Gramedia Pustaka Utama. 2010.

23. Kim H.S., Lee, J.Y., Lim, S.H., Cho, J., Kim, S.J., Jang, J.H., Kim, W.S., Jung, C.W., Kim, K. PatientGenerated Subjective Global Assessment as a prognosis tool in patients with multiple myeloma. Nutrition. 2016;36:67-71 DOI: 10.1016/j.nut.2016.06.009.

24. Wang AYM, Sea MMM, Ho ZSY, Lui SF, Li PKT, Woo J. Evaluation Of Handgrip Strength As A Nutritional Marker And Prognostic Indicator In Peritoneal Dialysis Patients. American Journal Clinical Nutrition. 2005;81:79-86.

25. Gallager D, Heymsfield SB, Heo M, Jebb SA, Murgatroyd PR, Sakamoto Y. Healthy Percentages Body Fat Ranges: An Approach For Developing

Copyright ( 2021; Jurnal Gizi Indonesia (The Indonesian Journal of Nutrition), Volume 10 (1), 2021

e-ISSN : 2338-3119, p-ISSN: 1858-4942 
Guideline Based On Body Mass Index. American Journal Clinical Nutrition. 2000;72:694-701.

26. Zeman FJ, Ney DM. Application of Clinical Nutrition. New Jersey: Prentice-Hall. 1998.

27. Wikes MG. Gizi pada Kanker dan Infeksi HIV (Nutrition for Cancer and HIV). Jakarta:PT. EGC. 2000.

28. Lorente, L., Rodriguez, S.T., Sanz, P., AbreuGonzalez, P., Diaz, D., Moreno, A.M., Borja, E., Martin, M.M., Jimenez, A., Barrera, M.A. Association Between Pre-Transplant Serum Malondialdehyde Levels And Survival One Year After Liver Transplantation For Hepatocellular Carcinoma. International Journal of Molecular Sciences. 2016;17:500.

29. Susetyowati. Penerapan Skrining Gizi di Rumah Sakit (Implementing Nutritional Screening Tool in Hospital). Yogyakarta : Universitas Gadjah Mada Press. 2014.

30. Cutsem EV, Arends J. The Cause and Consequences of Cancer-associated Malnutrition. European Journal of Oncology Nursing. 2005;9:561-563.

31. Argolo DF, Hudis CA, Iyengar NM. Obesity And Cancer-Opportunities To Break The Link. Current Breast Cancer Report. 2016;8:22-31.

32. Puspasari A. Perbedaan Kadar Hemoglobin pada Pasien Karsinoma Nasofaring Sebelum dan Setelah Radioterapi (The Difference of Hemoglobin in Nasopharynx Carcinoma Patients Before and After Radiotherapy). Semarang: Universitas Diponegoro Press. 2010.

33. American Institute for Cancer Research. Heal, Well, a Cancer Nutrition Guide: Healthy Eating and Activity for Living. 2013. 